\title{
Actions of Proteolytic Enzymes on Agglutinability of $M$ and $N$ Blood-group Red Cells
}

\author{
Kaoru Sagisaka, Kazuo Tokiwa and Naohumi Yoshioka \\ Department of Legal Medicine, ${ }^{*}$ School of Medicine, Iwate \\ Medical University, Morioka
}

\begin{abstract}
Sagtsaka, K., Tokrwa, K. and Yoshioka, N. Actions of Proteolytic Enzymes on Agglutinability of $M$ and $N$ Blood-group Red Cells. Tohoku J. exp. Med., 1972, 106 (2), 191-197 - The agglutinability of the proteolytic enzyme treated $\mathrm{M}, \mathrm{N}$ and $\mathrm{MN}$ red cells with any one of the anti-M and $-\mathrm{N}$ antisera, eluted antibodies and class antibodies was studied. The enzyme-treated $\mathrm{M}$ and $\mathrm{N}$ red cells lost their group specificity in agglutination with the absorbed antisera. However, it was noted that the enzyme-treated $M$ red cells acquired $N$ agglutinogen instead of losing their own M agglutinogen in agglutination with the eluted antibodies. The enzyme-treated $\mathrm{N}$ red cells maintained the group specificity. Agglutination of the enzyme-treated red cells with the class antibodies showed clearly that the changes in agglutinability of the red cells were caused by each of the class antibodies. proteolytic enzymes; MN blood groups
\end{abstract}

Serological effects of proteolytic enzymes on the red cells have been studied from various points of view, and examination of incomplete antibodies using the enzymes has been performed routinely in cases of the ABO and $\mathrm{Rh}-\mathrm{Hr}$ blood group systems. In the MN blood system, it has been pointed out that $\mathrm{M}$ and $\mathrm{N}$ agglutinogens are evidently changed by the enzyme treatment so that pan-agglutination of the enzyme-treated red cells is observed (Wiener and Katz 1951, Rosenfield and Vogel 1951). Moreover, Cook and Eylar (1965) reported that pronase, a proteolytic enzyme, acted on $\mathrm{M}$ and $\mathrm{N}$ blood group red cells to release sialic acid possessing $\mathrm{M}$ and $\mathrm{N}$ blood group activities. In this paper, agglutinability of the enzymetreated M, N and MN red cells with any one of the anti-M and $-\mathrm{N}$ antisera, eluted antibodies and class antibodies is described.

\section{Materials and Methods}

Proteolytic enzyme solutions: Pronase (Tokyo Kasei Co. Ltd., Tokyo) was dissolved at a concentration of $200 \mathrm{ng} / \mathrm{ml}$ in $0.145 \mathrm{M} \mathrm{NaCl}-0.05 \mathrm{M} \mathrm{CaCl}_{2}$ adjusted with $0.5 \mathrm{M} \mathrm{NaHCO}$ to pH 7.4. Bromelin (Nutritional Biochem. Corp., Cleveland, U.S.A.) was dissolved at a concentration of $5 \mathrm{mg} / \mathrm{ml}$ in $1 / 15 \mathrm{M}$ phosphate buffered saline, $\mathrm{pH} 5.5$. Trypsin, papain and ficin (Wako Pure Chemicals Co. Ltd., Tokyo) solutions in a concentration of $10 \mathrm{mg} / \mathrm{ml}$ were prepared with $0.01 \mathrm{M}$ phosphate buffered saline, $\mathrm{pH} 7.3$. At the experiments, each of trypsin, papain and ficin solutions was diluted 1:10 with saline. The enzyme solutions were stocked under $-20^{\circ} \mathrm{C}$ until the experiments.

Received for publication, July 3, 1971.

* Director: Prof. S. Katsura. 
Treatments of the red cells with the enzyme solutions: $\mathrm{M}, \mathrm{N}$ and $\mathrm{MN}$ fresh red cells washed with saline 5 times were separately incubated in ten-fold volumes of the enzyme solution for 45 minutes at $37^{\circ} \mathrm{C}$. After the treatment, the cells were washed with saline 5 times. The agglutinability of the cells was examined within 3 days after the treatment.

Anti- $M$ and $-N$ antisera, eluted antibodies and class antibodies: The absorbed anti$M$ and $-\mathrm{N}$ antisera, and eluted specific anti-M and $-\mathrm{N}$ antibodies were obtained from the immunized rabbit sera by the manner described previously (Katsura et al. 1971). Class anti-M and $-\mathrm{N}$ antibodies were prepared from the crude rabbit antisera by DEAE-cellulose column chromatography as described by Abelson and Rawson (1963). Goat anti-rabbit-serum serum was obtained from the goat immunized with rabbit serum. The precipitin titer, precipitin content and antiglobulin titer were $8,000,64$, and 8,000 , respectively. The goat antiserum was diluted ten times.

Agglutination: Agglutination of the enzyme-treated red cells was performed with routine tube technique. Antiglobulin tests were carried out on the sensitized red cells after washing one time with cold saline when the agglutination failed.

\section{Results}

1) Reactions of the enzyme-treated red cells with the absorbed anti- $M$ and $-N$ sera

The enzyme-treated $\mathrm{M}$ cells were agglutinated with not only anti-M antiserum but also anti-N. The changes of M agglutinogen were similarly observed on the red cells treated with each of the five kinds of proteolytic enzymes. The agglutinability of enzyme-treated $M$ cells with anti- $\mathrm{N}$ antiserum was almost equal to that with anti-M. But the agglutinability of enzyme-treated $\mathrm{M}$ cells with anti-M

TABLE 1. Agglutinin titers of the absorbed anti-M serum tested with the enzyme-treated red cells

\begin{tabular}{|c|c|c|c|c|c|c|c|c|c|}
\hline \multirow{2}{*}{ Enzymes } & \multirow{2}{*}{$\begin{array}{l}\text { Blood groups } \\
\text { of the cells }\end{array}$} & \multicolumn{8}{|c|}{ Agglutinin titers } \\
\hline & & $1: 1$ & $1: 2$ & $1: 4$ & $1: 8$ & $1: 16$ & $1: 32$ & $1: 64$ & $1: 128$ \\
\hline Trypsin & $\begin{array}{c}\mathrm{M} \\
\mathrm{N} \\
\mathrm{MN}\end{array}$ & $\begin{array}{l}\text { HH } \\
\text { Ht } \\
\text { Ht }\end{array}$ & $\begin{array}{l}\mathrm{H} \\
\mathrm{HH} \\
\mathrm{Ht}\end{array}$ & $\begin{array}{l}H \\
H \\
H\end{array}$ & $\begin{array}{l}H \\
H \\
H\end{array}$ & $\begin{array}{l}+ \\
+ \\
+\end{array}$ & - & $\begin{array}{l}- \\
- \\
-\end{array}$ & $\begin{array}{l}- \\
-\end{array}$ \\
\hline Papain & $\begin{array}{c}\mathrm{M} \\
\mathrm{N} \\
\mathrm{MN}\end{array}$ & $\begin{array}{l}\text { HI } \\
\text { HI } \\
H\end{array}$ & $\begin{array}{l}\text { H } \\
\text { HI } \\
\text { HI }\end{array}$ & $\begin{array}{l}H \\
H \\
H\end{array}$ & $\begin{array}{l}H \\
H \\
H\end{array}$ & $\begin{array}{l}+ \\
+ \\
+\end{array}$ & $\frac{1}{1}$ & $\begin{array}{l}- \\
- \\
-\end{array}$ & $\begin{array}{l}- \\
-\end{array}$ \\
\hline Ficin & $\begin{array}{c}\mathrm{M} \\
\mathrm{N} \\
\mathrm{MN}\end{array}$ & $\begin{array}{l}\text { H } \\
H \\
H\end{array}$ & $\begin{array}{l}H \\
\mathrm{H} \\
\mathrm{H}\end{array}$ & $\begin{array}{l}H \\
H \\
H\end{array}$ & $\begin{array}{l}H \\
H \\
H\end{array}$ & $\begin{array}{l}+ \\
+ \\
+\end{array}$ & $\frac{1}{1}$ & $\begin{array}{l}- \\
-\end{array}$ & $\begin{array}{l}- \\
- \\
-\end{array}$ \\
\hline Bromelin & $\underset{\mathrm{MN}}{\mathrm{M}}$ & $\begin{array}{l}\text { HH } \\
\text { HH } \\
\text { HH }\end{array}$ & $\begin{array}{l}\text { H } \\
\mathrm{H} \\
\mathrm{H}\end{array}$ & $\begin{array}{l}H \\
H \\
H\end{array}$ & $\begin{array}{l}H \\
+ \\
+\end{array}$ & $\begin{array}{l}+ \\
+ \\
+\end{array}$ & $\begin{array}{l}- \\
- \\
-\end{array}$ & $\begin{array}{l}- \\
- \\
-\end{array}$ & $\begin{array}{l}- \\
-\end{array}$ \\
\hline Pronase & $\begin{array}{c}\mathrm{M} \\
\mathrm{N} \\
\mathrm{MN}\end{array}$ & 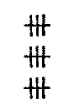 & $\begin{array}{l}\text { H } \\
\text { H } \\
\text { H }\end{array}$ & $\begin{array}{l}H \\
H \\
H\end{array}$ & $\begin{array}{l}+ \\
+ \\
+\end{array}$ & $\begin{array}{l}+ \\
+ \\
+\end{array}$ & $\frac{1}{\perp}$ & $\begin{array}{l}- \\
- \\
-\end{array}$ & $\begin{array}{l}- \\
-\end{array}$ \\
\hline Control & $\begin{array}{c}\mathrm{M} \\
\mathrm{N} \\
\mathrm{MN}\end{array}$ & $\frac{H}{H}$ & $\frac{H}{H}$ & $\frac{H}{H}$ & $\begin{array}{l}H \\
+\end{array}$ & $\begin{array}{l}+ \\
+ \\
+\end{array}$ & $\begin{array}{l}+ \\
+ \\
+\end{array}$ & $\begin{array}{l}+ \\
\perp\end{array}$ & - \\
\hline
\end{tabular}

$\#++$ Positive grades of agglutination. - Negative 
TABLE 2. Agglutinin titers of the absorbed anti-N serum tested with the enzyme-treated red cells

\begin{tabular}{|c|c|c|c|c|c|c|c|}
\hline \multirow{2}{*}{ Enzymes } & \multirow{2}{*}{$\begin{array}{l}\text { Blood groups } \\
\text { of the cells }\end{array}$} & \multicolumn{6}{|c|}{ Agglutinin titers } \\
\hline & & $1: 1$ & $1: 2$ & $1: 4$ & $1: 8$ & $1: 16$ & $1: 32$ \\
\hline Trypsin & $\begin{array}{c}\mathbf{M} \\
\mathbf{N} \\
\mathbf{M N}\end{array}$ & $\begin{array}{l}H \\
H \\
H\end{array}$ & $\begin{array}{l}H \\
H \\
+\end{array}$ & $\begin{array}{l}+ \\
+ \\
+\end{array}$ & $\begin{array}{l}+ \\
+ \\
\perp\end{array}$ & $\bar{\perp}$ & $\begin{array}{l}- \\
- \\
-\end{array}$ \\
\hline Papain & $\underset{\mathbf{M N}}{\mathbf{M}}$ & $\begin{array}{l}H \\
H \\
H\end{array}$ & $\begin{array}{l}\# \\
H \\
H\end{array}$ & $\begin{array}{l}+ \\
+ \\
+\end{array}$ & $\begin{array}{l}+ \\
+ \\
+\end{array}$ & $\begin{array}{l}+ \\
+ \\
-\end{array}$ & $\begin{array}{l}- \\
- \\
-\end{array}$ \\
\hline Ficin & $\underset{\mathrm{MN}}{\mathrm{M}}$ & $\begin{array}{l}H \\
H \\
H\end{array}$ & $\begin{array}{l}\# \\
H \\
H\end{array}$ & $\begin{array}{l}H \\
H \\
+\end{array}$ & $\begin{array}{l}+ \\
+ \\
+\end{array}$ & $\begin{array}{l}+ \\
+ \\
-\end{array}$ & $\begin{array}{l}- \\
- \\
-\end{array}$ \\
\hline Bromelin & $\begin{array}{c}\mathbf{M} \\
\mathbf{M N}\end{array}$ & $\begin{array}{l}H \\
H \\
H\end{array}$ & $\begin{array}{l}H \\
H \\
+\end{array}$ & $\begin{array}{l}H \\
+ \\
+\end{array}$ & $\begin{array}{l}+ \\
+ \\
\perp\end{array}$ & $\begin{array}{l}+ \\
+ \\
-\end{array}$ & $\begin{array}{l}- \\
- \\
-\end{array}$ \\
\hline Pronase & $\begin{array}{c}\mathrm{M} \\
\mathbf{N} \\
\mathrm{MN}\end{array}$ & $\begin{array}{l}H \\
H \\
H\end{array}$ & $\begin{array}{l}H \\
H \\
+\end{array}$ & $\begin{array}{l}H \\
H \\
+\end{array}$ & $\begin{array}{l}+ \\
+ \\
+\end{array}$ & $\begin{array}{l}+ \\
+ \\
-\end{array}$ & $\begin{array}{l}- \\
-\end{array}$ \\
\hline Control & $\begin{array}{c}\mathbf{M} \\
\mathbf{N} \\
\mathbf{M N}\end{array}$ & $\begin{array}{l}+ \\
H \\
H\end{array}$ & $\begin{array}{l}- \\
H \\
H\end{array}$ & $\begin{array}{l}- \\
H \\
H\end{array}$ & $\begin{array}{l}- \\
+ \\
+\end{array}$ & $\begin{array}{l}- \\
+ \\
+\end{array}$ & $\begin{array}{l}- \\
- \\
-\end{array}$ \\
\hline
\end{tabular}

antiserum was slightly lower than that of non-treated ones. The enzyme-treated $\mathrm{N}$ cells were agglutinated not only with anti-N antiserum but also anti-M. The reduction of agglutinability of enzyme-treated $\mathrm{N}$ red cells with anti-N antiserum was not apparent (Tables 1 and 2).

\section{2) Reactions of the enzyme-treated red cells with the eluted anti- $M$ and $-N$ antibodies}

The enzyme-treated M and MN red cells were agglutinated with the eluted anti$\mathrm{N}$ antibody but not with anti-M antibody. Therefore, it appeared that the enzyme-treated $M$ red cells acquired $N$ agglutinogen instead of losing their own $M$ agglutinogen. On the other hand, the enzyme-treated $\mathrm{N}$ red cells maintained their group specificity. However, agglutinability of the enzyme-treated $\mathrm{N}$ red cells with anti-N antibody decreased slightly. Especially, the $\mathrm{N}$ agglutinogen of $\mathrm{N}$ red cells treated with trypsin was evidently reduced. The same reduction was observed in cases of the enzyme-treated MN red cells. The antiglobulin test on the non-agglutinated red cells revealed that the enzyme-treated M, N and MN red cells had a slight reactivity to anti-M antibody (Tables 3 and 4).

\section{3) Reactions of the enzyme-treated red cells with the class antibodies}

The DEAE-cellulose column chromatography indicated, as shown in Fig. 1, that the rabbit crude antiserum consisted of IgG, IgA and IgM antibodies. The IgA fraction slightly surpassed the others in protein concentration and agglutinin titer. The titration of each of the classes was performed using only the 
TABLE 3. Agglutinin titers of the eluted anti-M antibody tested with the enzyme-treated red cells

\begin{tabular}{|c|c|c|c|c|c|c|c|c|}
\hline \multirow{2}{*}{ Enzymes } & \multirow{2}{*}{$\begin{array}{l}\text { Blood groups } \\
\text { of the cells }\end{array}$} & \multicolumn{7}{|c|}{ Agglutinin titers } \\
\hline & & $1: 1$ & $1: 2$ & $1: 4$ & $1: 8$ & $1: 16$ & $1: 32$ & $1: 64$ \\
\hline Trypsin & $\begin{array}{c}\mathrm{M} \\
\mathrm{N} \\
\mathrm{MN}\end{array}$ & $\begin{array}{l}-(+) \\
-(+) \\
-(t)\end{array}$ & $\begin{array}{l}-(+) \\
-(-) \\
-(+)\end{array}$ & $\begin{array}{l}-(-) \\
-(-) \\
-(-)\end{array}$ & $\begin{array}{l}-(-) \\
-(-) \\
-(-)\end{array}$ & $\begin{array}{l}-(-) \\
-(-) \\
-(-)\end{array}$ & $\begin{array}{l}-(-) \\
-(-) \\
-(-)\end{array}$ & $\begin{array}{l}-(-) \\
-(-) \\
-(-)\end{array}$ \\
\hline Papain & $\begin{array}{c}\mathrm{M} \\
\mathrm{N} \\
\mathrm{MN}\end{array}$ & $\begin{array}{l}-(+) \\
-(+) \\
-(+)\end{array}$ & $\begin{array}{l}-(+) \\
-(-) \\
-(+)\end{array}$ & $\begin{array}{l}-(-) \\
-(-) \\
-(-)\end{array}$ & $\begin{array}{l}-(-) \\
-(-) \\
-(-)\end{array}$ & $\begin{array}{l}-(-) \\
-(-) \\
-(-)\end{array}$ & $\begin{array}{l}-(-) \\
-(-) \\
-(-)\end{array}$ & $\begin{array}{r}-(-) \\
-(-) \\
-(-)\end{array}$ \\
\hline Ficin & $\begin{array}{c}\mathrm{M} \\
\mathrm{N} \\
\mathrm{MN}\end{array}$ & $\begin{array}{l}-(+) \\
-(+) \\
-(+)\end{array}$ & $\begin{array}{l}-(+) \\
-(-) \\
-(+)\end{array}$ & $\begin{array}{l}-(-) \\
-(-) \\
-(-)\end{array}$ & $\begin{array}{l}-(-) \\
-(-) \\
-(-)\end{array}$ & $\begin{array}{l}-(-) \\
-(-) \\
-(-)\end{array}$ & $\begin{array}{l}-(-) \\
-(-) \\
-(-)\end{array}$ & $\begin{array}{l}-(-) \\
-(-) \\
-(-)\end{array}$ \\
\hline Bromelin & $\begin{array}{c}\mathrm{M} \\
\mathrm{N} \\
\mathrm{MN}\end{array}$ & $\begin{array}{l}-(+) \\
-(+) \\
-(+)\end{array}$ & $\begin{array}{l}-(+) \\
-(-) \\
-(+)\end{array}$ & $\begin{array}{l}-(-) \\
-(-) \\
-(-)\end{array}$ & $\begin{array}{l}-(-) \\
-(-) \\
-(-)\end{array}$ & $\begin{array}{l}-(-) \\
-(-) \\
-(-)\end{array}$ & $\begin{array}{l}-(-) \\
-(-) \\
-(-)\end{array}$ & $\begin{array}{r}-(-) \\
-(-) \\
-(-)\end{array}$ \\
\hline Pronase & $\begin{array}{c}\mathrm{M} \\
\mathrm{N} \\
\mathrm{MN}\end{array}$ & $\begin{array}{l}-(+) \\
-(+) \\
-(+)\end{array}$ & $\begin{array}{l}-(+) \\
-(-) \\
-(+)\end{array}$ & $\begin{array}{l}-(-) \\
-(-) \\
-(-)\end{array}$ & $\begin{array}{l}-(-) \\
-(-) \\
-(-)\end{array}$ & $\begin{array}{l}-(-) \\
-(-) \\
-(-)\end{array}$ & $\begin{array}{l}-(-) \\
-(-) \\
-(-)\end{array}$ & $\begin{array}{l}-(-) \\
-(-) \\
-(-)\end{array}$ \\
\hline Control & $\frac{M}{N}$ & $\begin{array}{c}H \\
-(-) \\
H\end{array}$ & $\begin{array}{c}H \\
-(-) \\
H\end{array}$ & $\begin{array}{c}H \\
-(-) \\
H\end{array}$ & $\begin{array}{c}+4 \\
-(-) \\
H\end{array}$ & $\begin{array}{c}H \\
-(-) \\
H\end{array}$ & $\begin{array}{c}+ \\
-(-) \\
+\end{array}$ & $\begin{array}{c}\frac{1}{1} \\
1\end{array}$ \\
\hline
\end{tabular}

The results of antiglobulin tests are shown in parentheses.

TABLE 4. Agglutinin titers of the eluted anti-N antibody tested with the enzyme-treated red cells

\begin{tabular}{|c|c|c|c|c|c|c|c|}
\hline \multirow{2}{*}{ Enzymes } & \multirow{2}{*}{$\begin{array}{l}\text { Blood groups } \\
\text { of the cells }\end{array}$} & \multicolumn{6}{|c|}{ Agglutinin titers } \\
\hline & & $1: 1$ & $1: 2$ & $1: 4$ & $1: 8$ & $1: 16$ & $1: 32$ \\
\hline Trypsin & $\begin{array}{c}\mathrm{M} \\
\mathrm{N} \\
\mathrm{MN}\end{array}$ & $\begin{array}{l}+ \\
+ \\
+\end{array}$ & $\begin{array}{l}+ \\
+ \\
+\end{array}$ & $\begin{array}{l}\frac{1}{+} \\
+\end{array}$ & $\begin{array}{l}- \\
- \\
-\end{array}$ & $\begin{array}{l}- \\
- \\
-\end{array}$ & $\begin{array}{l}- \\
-\end{array}$ \\
\hline Papain & $\begin{array}{c}\mathrm{M} \\
\mathrm{N} \\
\mathrm{MN}\end{array}$ & $\begin{array}{l}H \\
+ \\
H\end{array}$ & $\begin{array}{l}H \\
+ \\
H\end{array}$ & $\begin{array}{l}H \\
+ \\
+\end{array}$ & $\begin{array}{l}+ \\
+ \\
+\end{array}$ & $\begin{array}{l}+ \\
+ \\
+\end{array}$ & $\begin{array}{l}- \\
- \\
-\end{array}$ \\
\hline Ficin & $\begin{array}{c}\mathrm{M} \\
\mathrm{N} \\
\mathrm{MN}\end{array}$ & $\begin{array}{l}H \\
H \\
H\end{array}$ & $\begin{array}{l}H \\
H \\
H\end{array}$ & $\begin{array}{l}+ \\
+ \\
+\end{array}$ & $\begin{array}{l}+ \\
+ \\
+\end{array}$ & $\begin{array}{l}+ \\
+ \\
+\end{array}$ & $\begin{array}{l}- \\
-\end{array}$ \\
\hline Bromelin & $\begin{array}{c}\mathrm{M} \\
\mathrm{N} \\
\mathrm{MN}\end{array}$ & $\begin{array}{l}H \\
H \\
H\end{array}$ & $\begin{array}{l}H \\
H \\
H\end{array}$ & $\begin{array}{l}+ \\
+ \\
+\end{array}$ & $\frac{\perp}{\perp}$ & $\begin{array}{l}- \\
-\end{array}$ & - \\
\hline Pronase & $\begin{array}{c}\mathrm{M} \\
\mathrm{N} \\
\mathrm{MN}\end{array}$ & $\begin{array}{l}H \\
H \\
H\end{array}$ & $\begin{array}{l}H \\
H \\
H\end{array}$ & $\begin{array}{l}+ \\
+ \\
+\end{array}$ & $\begin{array}{l}+ \\
+ \\
\perp\end{array}$ & $\begin{array}{l}- \\
-\end{array}$ & $\begin{array}{l}- \\
-\end{array}$ \\
\hline Control & $\begin{array}{c}\mathrm{M} \\
\mathrm{N} \\
\mathrm{MN}\end{array}$ & $\begin{array}{l}- \\
H \\
H\end{array}$ & $\begin{array}{l}- \\
+ \\
H\end{array}$ & $\begin{array}{l}- \\
+ \\
+\end{array}$ & $\begin{array}{l}- \\
+ \\
+\end{array}$ & $\frac{-}{\perp}$ & $\begin{array}{l}- \\
-\end{array}$ \\
\hline
\end{tabular}




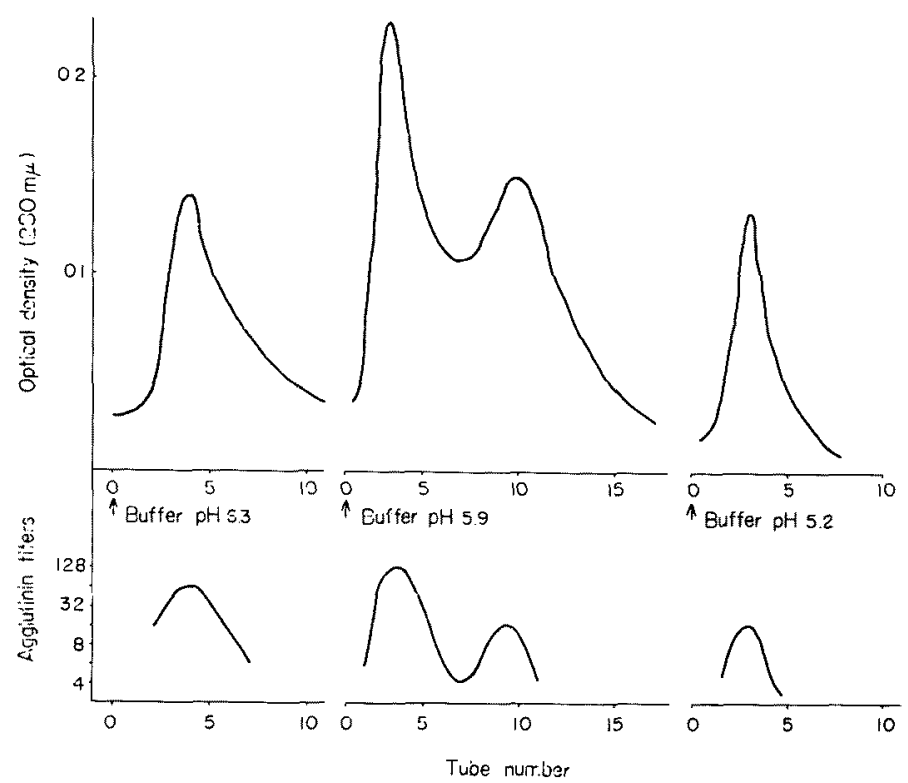

Fig. 1. DEAE-cellulose column chromatography of the rabbit crude anti-N serum. The chromatography was carried out with $0.2 \mathrm{ml}$ of the serum (agglutinin titer anti$\mathrm{N} 1: 10,240$, anti-M $1: 5,120$ ) and the column bed $1 \times 18 \mathrm{~cm}$ in size using phosphate bufferes reported by Abelson and Rawson. Titrations of each of the effluents $2 \mathrm{ml}$ were performed by the tube test. Agglutinations of the effluents obtained from initial buffer were made on the red cells supended in $0.28 \mathrm{M} \mathrm{NaCl}$ solution.

trypsin-treated red cells. The agglutination of the enzyme-treated $\mathrm{M}$ and $\mathrm{N}$ red cells with IgG obtained from anti-M and $-\mathrm{N}$ antisera (anti-M IgG and anti-N IgG) was similar to that with the eluted antibodies. On the other hand, the enzymetreated $M$ red cells were agglutinated only with the undiluted anti-M IgG. The agglutinability of the enzyme-treated $M$ red cells with anti-M IgM and that of the enzyme-treated $\mathrm{N}$ red cells with anti-N IgG were similar to that of the non-treated red cells with the class antibodies. However, the agglutinability of the enzymetreated red cells with IgA obtained from anti-M and $-\mathrm{N}$ antisera and that with IgM from anti-N antiserum were higher than that of the non-treated red cells with the class antibodies. In antiglobulin tests, the titer of the enzymetreated $\mathrm{M}$ red cells against anti-M IgG was 1:2 (Tables 5 and 6).

\section{Discussion}

Actions of many proteolytic enzymes on hemagglutination have been studied since Morton and Pickles (1947) reported that the trypsin-treated cells could be agglutinated with the incomplete $\mathrm{Rh}$ antibody in saline. On the MN blood group system, it has been pointed out that the enzyme treatment resulted in changes of the agglutinogens of the red cells and both $M$ and $N$ red cells treated with trypsin behaved as MN red cells (Wiener and Katz 1951, Rosenfield and Vogel 1951, 
TABLE 5. Agglutinin titers of the anti $M$ classes tested with the trypsin-treated red cells

\begin{tabular}{c|r|c|c|c|c|c|c|c|c}
\hline \multirow{2}{*}{ Classes } & \multirow{8}{*}{ Red cells } & \multicolumn{7}{|c}{ Agglutinin titers } \\
\cline { 2 - 9 } & & $1: 1$ & $1: 2$ & $1: 4$ & $1: 8$ & $1: 16$ & $1: 32$ & $1: 64$ & $1: 128$ \\
\hline \multirow{2}{*}{ IgG } & Treated M & $+(+)$ & $-(+)$ & $-(-)$ & $-(-)$ & $-(-)$ & $-(-)$ & $-(-)$ & $-(-)$ \\
& Non-treated M & + & $H$ & + & + & + & + & $\perp$ & - \\
IgA & Treated M & + & $H$ & + & + & + & + & - & - \\
& Non-treated M & + & $H$ & + & + & + & - & - & - \\
IgM & Treated M & + & + & + & - & - & - & - & - \\
& Non-treated M & + & + & + & - & - & - & - & -
\end{tabular}

The results of antiglobulin testes are shown in parentheses.

TABLE 6. Agglutinin titers of the anti- $N$ classes tested with the trypsin-treated red cells

\begin{tabular}{|c|c|c|c|c|c|c|c|c|c|c|}
\hline \multirow{2}{*}{ Classes } & \multirow{2}{*}{ Red cells } & \multicolumn{9}{|c|}{ Agglutinin titers } \\
\hline & & $1: 1$ & $1: 2$ & $1: 4$ & $1: 8$ & $1: 16$ & $1: 32$ & $1: 64$ & $1: 128$ & $1: 256$ \\
\hline $\operatorname{IgG}$ & $\begin{array}{r}\text { Treated N } \\
\text { Non-treated N }\end{array}$ & $\begin{array}{l}H \\
H\end{array}$ & \# & $\begin{array}{l}H \\
H\end{array}$ & $\begin{array}{l}H \\
H\end{array}$ & $\begin{array}{l}H \\
H\end{array}$ & $\begin{array}{l}H \\
H\end{array}$ & $\begin{array}{l}+ \\
+\end{array}$ & $\begin{array}{l}+ \\
-\end{array}$ & - \\
\hline $\operatorname{IgA}$ & $\begin{array}{r}\text { Treated N } \\
\text { Non-treated N }\end{array}$ & \# & H & $\begin{array}{l}H \\
+\end{array}$ & H & $\begin{array}{l}+ \\
-\end{array}$ & $\begin{array}{l}+ \\
-\end{array}$ & - & - & $\begin{array}{l}- \\
-\end{array}$ \\
\hline IgM & $\begin{array}{r}\text { Treated N } \\
\text { Non-treated N }\end{array}$ & \# & $\begin{array}{l}\text { H } \\
+\end{array}$ & $\begin{array}{l}H \\
+\end{array}$ & H & \pm & $\begin{array}{l}+ \\
-\end{array}$ & - & - & $\begin{array}{l}- \\
-\end{array}$ \\
\hline
\end{tabular}

Tomita and Sone 1962). In the present studies, it was apparent that the enzymetreated $\mathrm{M}$ and $\mathrm{N}$ red cells were grouped as $\mathrm{MN}$ when the absorbed antisera were used. But the agglutination with the eluted antibodies demonstrated that the enzyme-treated M, N and MN red cells lost completely their agglutinability for anti-M antibody and that all group red cells reacted similarly with anti-N antibody.

The present authors (Katsura et al. 1971) reported recently that the absorbed antisera consisted of IgG and IgA, and the eluted antibody only IgG. Therefore, it was regarded that the reactivity of the enzyme-treated $M$ cells to IgG antibody was abolished by the enzyme treatment. It could be ascertained by the agglutination with the class antibodies that the enzyme-treated $M$ red cells lost their agglutinability with IgG antibody. However, a slight agglutination of the enzyme-treated M red cells with IgG antibody was observed by antiglobulin test. These results suggested that the enzyme treatment of M red cells changed their bivalent agglutinability to univalent one. It was noted also that the agglutinability of the enzyme-treated $\mathrm{N}$ red cells with IgA or IgM antibody was raised. From the above results, it was suggested that actions of the enzymes to $\mathrm{M}$ and $\mathrm{N}$ red cells were essentially different. Recently, Matsumoto et al. (1971) reported a case of the MN blood-group incompatible pregnancy, in which the mother had high-titered anti-M antibody $(1: 1,024)$. In addition, they demonstrated that trypsin-treated $\mathrm{O}, \mathrm{M}$ and $\mathrm{O}, \mathrm{MN}$ red cells did not react with the mother's 
antibody, which was confirmed to be a $7 \mathrm{~s}$ immuno-globulin. These findings coincided well with the results of the present investigation.

The agglutinin titer $(1: 64)$ of IgG antibody tested with the non-treated $M$ red cells decreased to $1: 1$ when the antibody was examined with the trypsintreated $M$ red cells. This result, however, did not suggest that the enzymetreated $\mathrm{M}$ red cells could be agglutinated with the high-titered anti-M IgG, because the anti-M IgG obtained from the crude anti-M serum contained a large amount of non-specific agglutinins.

It must be considered too that a small amount of the proteolytic enzyme present in the treated red cells may act on the antibodies added in the agglutination, because it is well known that proteolytic enzymes can split the antibody into smaller molecular proteins. However, agglutination of the boiled red cells after treatment with enzymes, which will be presented in a separate report, may be able to refute the above-mentioned view.

\section{Acknowledgment}

We wish to express our thanks to Prof. S. Katsura for his advice and encouragement.

\section{References}

1) Abelson, N.M. \& Rawson, A.J. (1963) The rexctions between blood group antibodies and antisera to purified immunoglobulins. Transfusion, 3, 469-482.

2) Cook, G.M.W. \& Eylar, E.H. (1965) Separation of the $M$ and N blood-group antigens of the human erythrocyte. Biochim. Biophys. Acta, 101, 57-66.

3) Katsura, S., Sagisaka, K., Sugisawa, H., Tokiwa, K. \& Mochizuki, K. (1971) Studies on the preparations of the specific anti-M and anti- $N$ antibodies by means of the absorption-elution. Jap. J. legal Med., 25, 91-102.

4) Matsumoto, H., Miyazaki, T. \& Mabuchi, Y. A case of erythroblastosis fetalis caused by anti-M. Communication presented at the 55th Conference of the Medico-legal Society of Japan held in Tokyo, on April 3rd in 1971.

5) Morton, J.A. \& Pickles, M.M. (1947) Use of trypsin in the detection of incomplete anti-Rh antibodies. Nature, 159, 779-780.

6) Tomita, K. \& Sone, Y. (1962) On the complete and incomplete agglutinins in the immune anti-M and anti-N rabbit sera. Hiroshima J. med. Sci., 11, 59-61.

7) Rosenfield, R.E. \& Vogel, P. (1951) The identification of hemagglutinins with red cells altered with trypsin. Trans. N.Y. Acad. Sci., 13, 213-220.

8) Wiener, A.S. \& Katz, L. (1951) Studies on the use of enzyme-treated red cells in tests for Rh sensitization. $J$. Immunol., 66, 51-66. 